Hana Kř́ižová1, Viktor Tuček'1, Jitka Neoralová2, Jakub Wiener ${ }^{1}$

${ }^{1}$ Technical University of Liberec, Faculty of Textile Engineering, Department of Material Engineering,

Studentská 2, Liberec, Czech Republic

${ }^{2}$ National Library of the Czech Republic, Development and Research Laboratories, Sodomkova 2, Prague,

Czech Republic

\title{
Buffering and Antibacterial Properties of Cotton Canvas with Dolomite/ZnO-Styrene-Acrylic Complex Coating and their Comparison with Properties after the Accelerated Aging
} Puferske in protibakterijske lastnosti bombažne tkanine z dolomit/ZnO-stiren-akrilnim kompleksnim premazom in primerjava lastnosti po pospešenem staranju

\author{
Original Scientific Article/lzvirni znanstveni članek \\ Received/Prispelo 08-2017 • Accepted/Sprejeto 09-2017
}

\begin{abstract}
In this study, we report evaluation of buffering and self-sterilizing coating complex obtained by dolomite and zinc oxide particles incorporation into styrene-acrylic layer applied to cotton fabric. Surface properties of the coating were evaluated by SEM, EDS and 3D optical microscopy. Antimicrobial properties were determined using a mixture of G+ and G- bacteria (Escherichia coli, Staphylococcus epidermidis and Streptococcus mutans) that was in dynamic contact with canvases for 4-100 hours. Alkalizing - buffer capacity of the surface layer supplied to the system by dolomite was tested by the addition of acetic acid. All these properties were simultaneously tested on the same canvases that have been previously exposed to the so-called hot $\left(105^{\circ} \mathrm{C}\right)$ and wet aging $\left(80^{\circ} \mathrm{C}, 65 \%\right.$ relative humidity). The aging was provided in the climatic test room for 144 hours and the properties of canvases before and after aging were compared and evaluated.

Keywords: dolomite, zinc oxide, acrylic coating, antibacterial, bicarbonate buffer
\end{abstract}

\section{Izvleček}

$\checkmark$ študiji je podana ocena puferskega in samosterilizajočega učinka stirenakrilnega kompleksnega premaza z dodatkom delcev dolomita in cinkovega oksida na bombažni tkanini. Površinske lastnosti premaza so bile ovrednotene s SEM, EDS in 3D optično mikroskopijo. Protimikrobne lastnosti so bile določene z uporabo mešanice gram pozitivnih in gram negativnih bakterij (Escherichia coli, Staphylococcus epidermidis in Streptococcus mutans), ki so bile $v$ dinamičnem stiku s tkanino od 4 do 100 ur. Bazično-pufersko zmogljivost premaza, ki so jo ustvarili z dodatkom delcev dolomita, so testirali z dodatkom ocetne kisline. Vse omenjene lastnosti so bile sočasno preizkušene na vzorcih tkanine, ki so bili pred tem izpostavljeni t. i. vročemu (pri $105^{\circ} \mathrm{C}$ ) in mokremu staranju (pri $80^{\circ} \mathrm{C}$, 65-odstotni relativni vlažnosti). Staranje je trajalo 144 urv klimatiziranem prostoru. Lastnosti vzorcev so bile ovrednotene in primerjane pred staranjem in po njem.

Ključne besede: dolomit, cinkov oksid, akrilni premaz, protibakterijske lastnosti, bikarbonatni pufer

Corresponding author/Korespondenčna avtorica: Mgr. Ing. Bc. Hana Kř́žová, Ph.D.

E-mail: hana.krizova@tul.cz
Tekstilec, 2017, 60(4), 275-282

DOl: 10.14502/Tekstilec2017.60.275-282 


\section{Introduction}

Composite materials based on metal (nano)particles attract significant attention due a wide range of physical-chemical properties. These materials are not simply physical mixtures and they can be defined as complex materials with organic and inorganic components intimately mixed. Modification of coating polymeric matrices leads to novel properties such as growth prevention or adhesion reduction of microorganisms. There is a significant interest in the development of antimicrobial and durable materials for application in the food and biomedical industries. These materials are also used in the fields, such as archiving, museums, librarianship, preservation or storage, where extension of lifetime of the books and other ageing objects is a necessity. These materials should combine desirable attributes such as potent bactericidal and fungicidal efficiency, environmental safety, low toxicity, and easy, cost-effective fabrication.

Carbonates are salts of carbonic acid and occur in the form of minerals and rocks commonly found in nature. Especially alkaline earth metal carbonates $\left(\mathrm{Ca}^{2+}\right.$ and $\left.\mathrm{Mg}^{2+}\right)$ are very widely used in many productions and industrial processes in various industries like construction [1], food [2], metallurgy [3], treatment of contaminated water and soil $[4,5]$, and fertilizers [6]. Calcium carbonate $\mathrm{CaCO}_{3}$ (limestone) occurs in many crystalline modifications (calcite, aragonite, alabaster, travertine, marble). Also, magnesium carbonate $\mathrm{MgCO}_{3}$ and calcium magnesium carbonate $\mathrm{CaMg}\left(\mathrm{CO}_{3}\right)_{2}$ are naturally found in many modifications, varieties and with different chemical impurities (Fe, $\mathrm{Mn}, \mathrm{Zn}, \mathrm{Pb}$ and others) [7]. Dolomite is a non-toxic, inexpensive, widely available double carbonate with slightly alkaline and buffering capabilities. It crystallizes in the trigonalrhombohedral system and depending on the admixture it is white, gray or pink. Unlike bicarbonates, carbonates, except for ammonium carbonate and alkali metal carbonates, are practically insoluble in water. Carbonates are important environmental buffering agents. They are part of the carbon dioxide/bicarbonate/carbonate buffer, which, above all, serve the world's oceans to neutralize and counterbalance acidic influences in the environment. This buffering system is essential in many biological processes such as maintaining a constant blood $\mathrm{pH}$ [8] and internal environment within homeostasis [1]:

$\mathrm{CO}_{2}+\mathrm{H}_{2} \mathrm{O} \leftrightarrows \mathrm{H}_{2} \mathrm{CO}_{3} \leftrightarrows \mathrm{HCO}_{3}^{-}+\mathrm{H}^{+}$
Comparison with Properties after the Accelerated Aging

Zinc oxide $\mathrm{ZnO}$ at low concentration is non-toxic to human and displays good biocompatibility to human cells. $\mathrm{ZnO}$ showed a wide range of antibacterial activities of different microorganisms, including both Gram-negative and Gram-positive bacteria [9]. It was also confirmed that reinforcement of $\mathrm{ZnO}$ in the biocomposites introduces their antibacterial activity [10].

\section{Experimental part}

\subsection{Preparation of samples}

Cotton fabric (Royal, PK) was used for preparation of coated canvas (area weight $156 \mathrm{~g} / \mathrm{m}^{2}$, thickness $0.29 \mathrm{~mm}$, plain weave, fineness of warp yarn 50 tex, fineness of weft yarn 40 tex, warp density 270 ends $/ 10 \mathrm{~cm}$ (68.6 ends per inch), weft density 230 picks $/ 10 \mathrm{~cm}$ (58.4 pics per inch), pre-dyed with the Direct Green 28 (CI No. 14155, azodye, concentration $0.5 \%$ ), coated with starch on the reverse side, width $50 \mathrm{~cm}$. Acronal S $996 \mathrm{~S}$ (BASF SE, GE) - aqueous polymer dispersion based on ester of acrylic acid and styrene (viscosity of $2 \mathrm{Ns} / \mathrm{m}^{2}$ ) was used as a basic coating paste. All following additives were thoroughly mixed into this basic matrix: laboratory-prepared cellulose dispersion to increase strength $[11,12]$, granulated natural pink dolomite (Forestina, CZ), powdered zinc oxide declared as nanoparticles (Bochemie, CZ), two benzisothiazole pigments: Aquacolors Red (temperature resistance $160-180{ }^{\circ} \mathrm{C}$ and light fastness $5-6$, $\mathrm{pH}$ 7.5; Sioen, BE), and Aquapaste Green 856 (temperature resistance to $200{ }^{\circ} \mathrm{C}$ and light fastness $8, \mathrm{pH} 8$; Orgapaste, FR). The resulting composition of the paste was as follows:

- $340 \mathrm{~g}$ of cellulose dispersion ( $8 \%$ of dry matter),

- $54 \mathrm{~g}$ of dolomite,

- $72 \mathrm{~g}$ of $\mathrm{ZnO}$ pulver,

- $162 \mathrm{~g}$ of water,

- $1800 \mathrm{~g}$ of styrene-acrylic basis,

- $40 \mathrm{~g}$ of thickener AXILAT 44 Bulk (Momentive Specialty Chemicals, CZ),

- $5.4 \mathrm{~g}$ of red pigment $(0.3 \%)$ and

- $64.8 \mathrm{~g}$ of green pigment (3.6\%).

The 2-layers coating was performed on the Coatema device (Coatema Coating Machinery $\mathrm{GmbH}$, $\mathrm{DE})$ : 1st passage was done at speed of $2.13 \mathrm{~m} / \mathrm{min}$, temperature of $130{ }^{\circ} \mathrm{C}$, and downforce of $150 \mathrm{~N}$, 2nd passage at speed of $3.55 \mathrm{~m} / \mathrm{min}$, temperature of 
$130{ }^{\circ} \mathrm{C}$, and downforce of $200 \mathrm{~N}$. The coated canvas had an area weight of $220 \mathrm{~g} / \mathrm{m}^{2}$ and a thickness of $0.33 \mathrm{~mm}$. Part of the canvas was subjected to the artificial accelerated aging. According to standards $[13,14]$ for accelerated aging of paper and board by dry heat treatment or moist heat treatment, part of the canvas was subjected to the so-called hot aging (at $105^{\circ} \mathrm{C}$ for 144 hours), another part of the canvas was subjected to the so-called wet aging (at $80{ }^{\circ} \mathrm{C}$ and $65 \%$ of relative humidity for 144 hours). Artificial aging was carried out in the WK3 climatic test room with a capacity of about 350 liters (Weiss Umwelttechnik GmbH, Reiskirchen, GE). Wet aging imitates weathering and weather influences or storage in wet and warm environment, while hot aging imitates dry tropics or other long-term high temperature stress. It is difficult to imitate experimentally the influence of time. The relation between accelerated and natural aging represents a serious problem. The changes monitored upon accelerated aging procedures must be correctly extrapolated to the ambient conditions. Nevertheless, in accordance with data in the literature, it is stated that three days of accelerated aging of paper and other cellulosic materials at $105{ }^{\circ} \mathrm{C}$ correspond to 25 years of natural aging [15].

\subsection{Characterization of coating surfaces}

The particle size used as additives and the appearance of the coated surface were scanned by optical methods. Particle size of $\mathrm{ZnO}$ and dolomite was measured using the particle size analyzer and laser scattering device (HORIBA LA-920, JP). The surface and cross-section of canvas were monitored using SEM scanning electron microscope VEGA TS 5130 (TESCAN, CZ) and the 3D digital multifunction microscope HIROX RH 2000 with MXB 2500REZ lens and diffuse adapter (HIROX, JP). This optical method also characterized the canvas surface roughness, $R z$. In accordance with standard JIS [16], $R z$ is the sum of the average absolute value of then height (five highest peaks) and the average absolute value of the depth (five lowest valleys from the average line of the roughness curve) on the weft yarn, in microns. Ten-spot average roughness was chosen at zoom 500-x. Energy-dispersive X-ray spectroscopy (EDS), when backscattered electrons at a sampling depth of 1-2 microns characterize the chemical composition of investigated surface, is part of SEM device. EDS was chosen as a method of chemical characterization of the coating surface and percentage quantification of the monitored metals (Zn, Ti, Ca, Mg).

\subsection{Buffering test}

$25 \mathrm{~cm}^{2}$ of each canvas including the reference sample (cotton fabric coated with only acrylic coating without additives) was immersed in $50 \mathrm{ml}$ of purified deionized water for 2 days at $22 \pm 2{ }^{\circ} \mathrm{C}$ to achieve an equilibrium of water with both $\mathrm{CO}_{2}$ from the atmosphere and carbonate containing dolomite. After 48 hours, the $\mathrm{pH}$ of the water in each beaker was measured. Then $0.5 \mathrm{ml}$ of $27 \mathrm{mM}$ acetic acid was added to each beaker. All pH changes were continuously potentiometrically measured at various time intervals up to 24 hours after application of acetic acid using glass silver chloride reference electrode.

\subsection{Microbiological test}

A mixture of G+ and G- bacteria containing $E$. coli, Staphylococcus epidermidis and Streptococcus mutans was prepared using a liquid culture medium Trypto-Soya Broth (TSB) (Biovendor, CZ) at $37{ }^{\circ} \mathrm{C}$ for 24 hours. Bacterial suspension of concentration $3 \cdot 10^{5} \mathrm{CFU} / \mathrm{ml}$ was prepared by dilution with distilled water. Thirty $\mathrm{ml}$ of this suspension was dosed into plastic tubes, samples of all four canvas were added (each with an area of $32 \mathrm{~cm}^{2}$ ), i.e. canvas without aging, canvas after hot aging, canvas after wet aging, and comparative sample (canvas without addition of additives). One tube with bacterial suspension was left without the addition of canvas. All samples inserted into the bacterial suspension in tubes were shaken on a shaker at speed of $150 \mathrm{rpm}$ to achieve dynamic contact of the bacterial suspension with the canvas surface. After 4, 48 and 72 hours, $1 \mathrm{ml}$ of suspension was taken from each tube, it was spotted on the surface of the agar in Petri dishes (TSA-Tryptone soya agar, Biovendor, CZ). These samples were cultivated at $37{ }^{\circ} \mathrm{C}$ for 24 hours and then bacterial colonies were counted.

\section{Results}

Results of particle size measurement using device HORIBA LA-920 (Figure 1 and Figure 2) show that the particle size ranged between 0.5 and 80 microns 


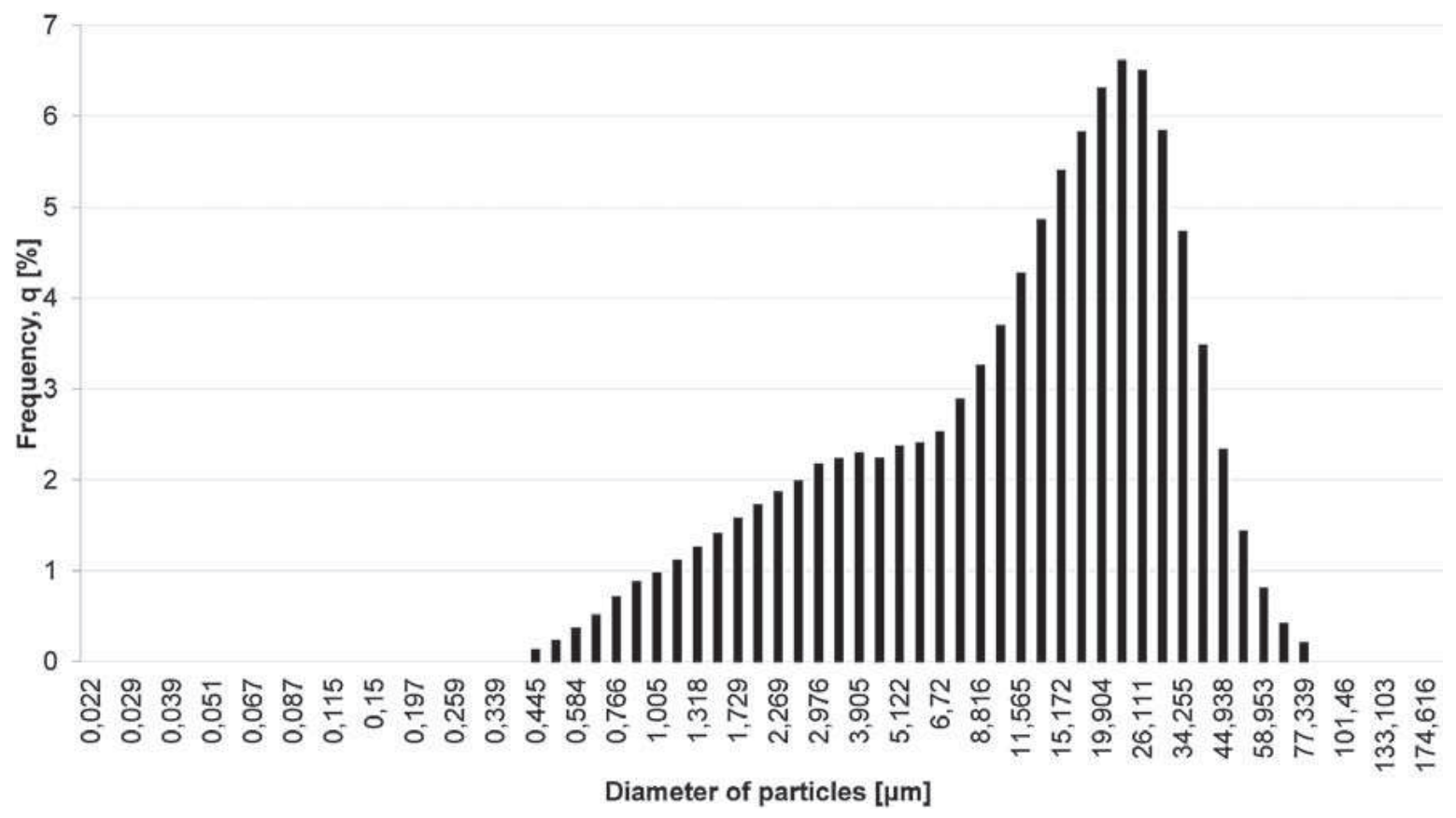

Figure 1: Distribution of dolomite particle size

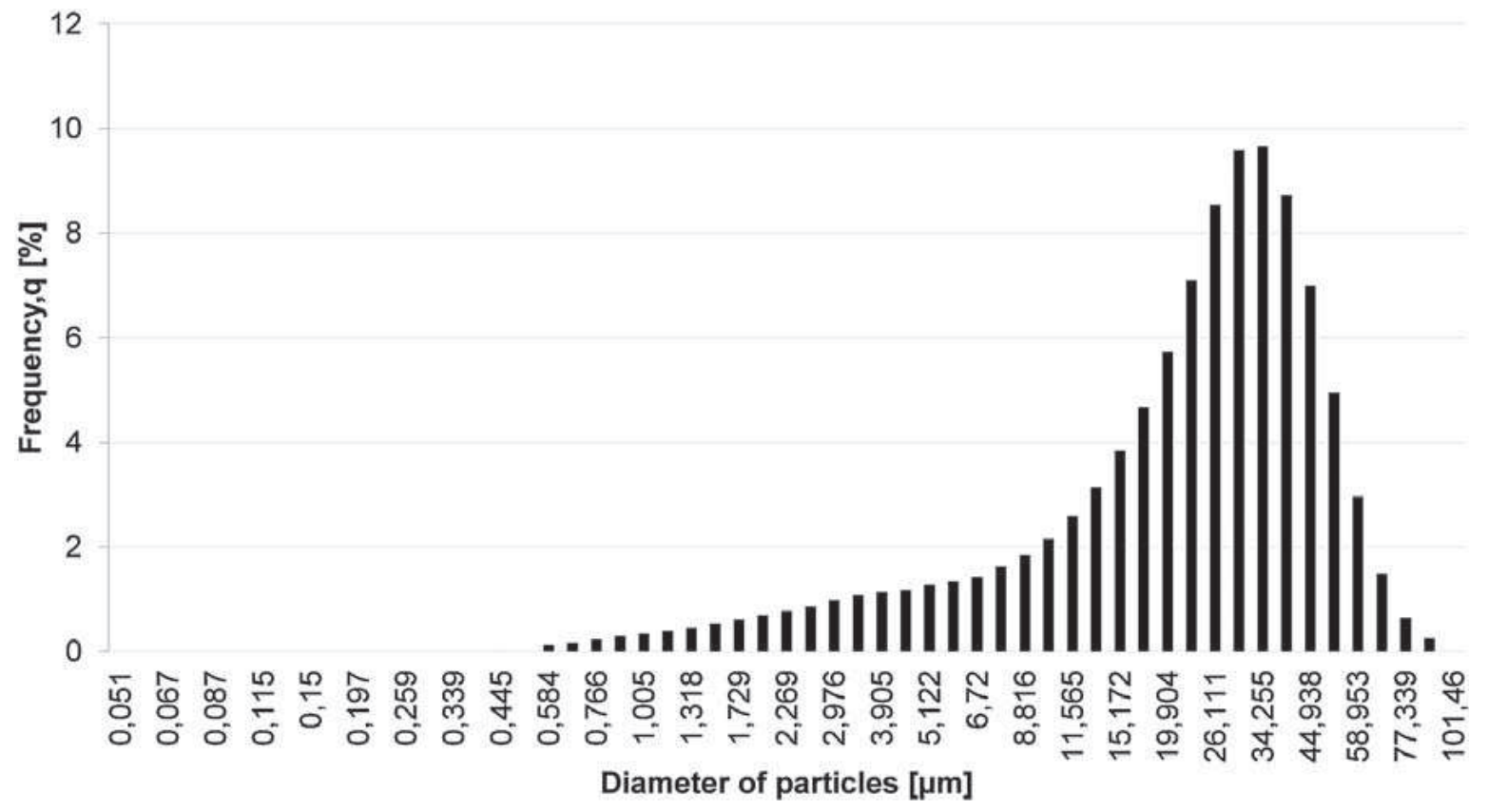

Figure 2: Distribution of $\mathrm{ZnO}$ particle size

for both dolomite and zinc oxide. While the mean of the dolomite particle size was $15.7 \mu \mathrm{m}$ and the median of $13 \mu \mathrm{m}$, the powder $\mathrm{ZnO}$ declared by the producer as nanoparticles had a mean particle size of 25 $\mu \mathrm{m}$ (median of $24 \mu \mathrm{m}$ ) due their easy agglomeration when used in a powdered state without a dispersant. Unfortunately, the shear forces used in the standard mechanical mixing of the coating composition under laboratory conditions were not sufficient to scatter $\mathrm{ZnO}$ agglomerates into nanoparticle sizes.

As can be seen from the surface (Figure 3 ) and the cross-section (Figure 4) SEM images of the canvas, this particle size also reflected in a relatively high surface roughness. The $R z$ value was calculated as 
10 microns using 3D microscope at a magnification of 500x (Figure 5).

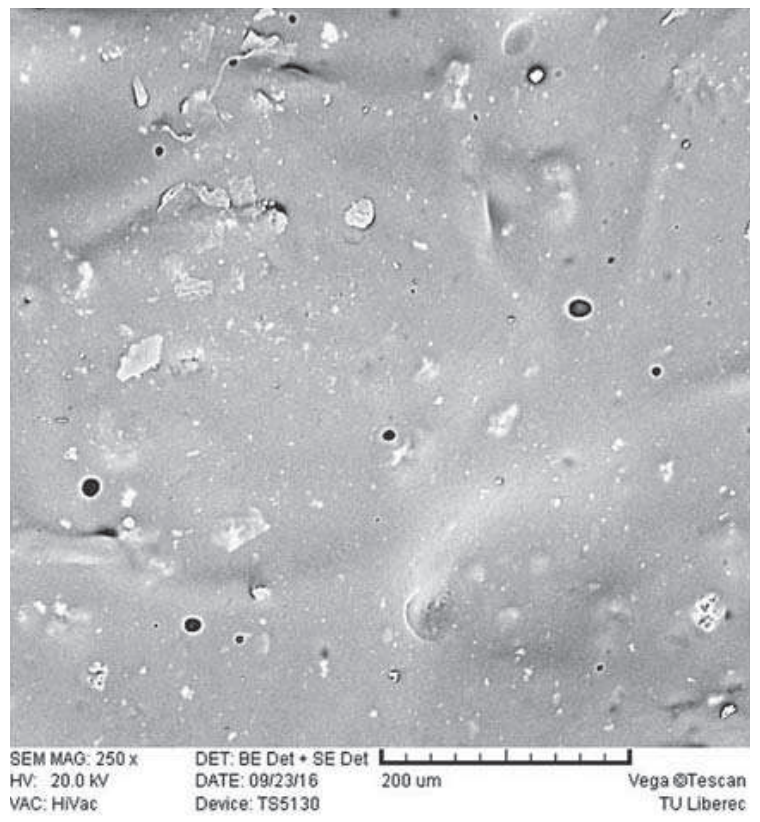

Figure 3: SEM image of canvas surface

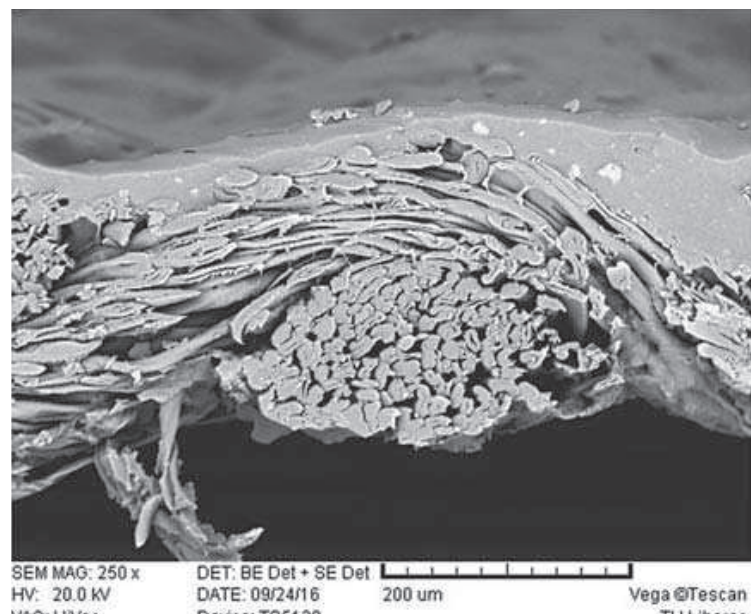

Figure 4: SEM image of canvas cross-section

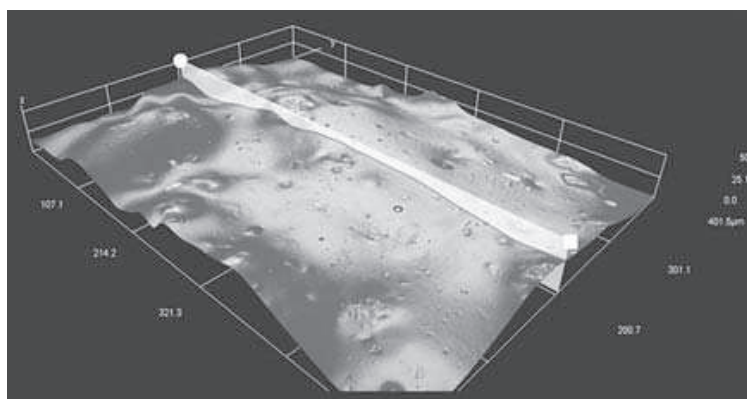

Figure 5: Surface roughness of canvas (3D HIROX, $500 x)$
The EDS spectra of the canvas surface were measured by SEM at the values of the middle vacuum (3-150 $\mathrm{Pa}$ ) and was taken from two locations (Figure 6): 1 - spot particle point (in place of surface irregularity in the coating), 2 - area (element mapping).

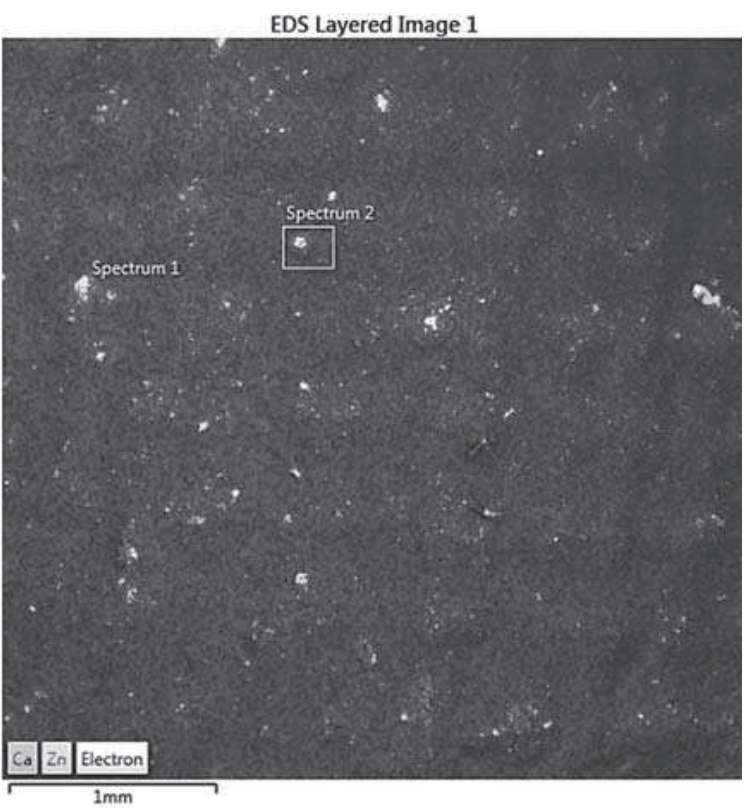

Figure 6: Two sites of EDS analysis (spot Spectrum 1 and small area Spectrum 2) and calcium-zinc occurrence mapping on the canvas surface

As shown in Figure 7 and Figure 8, for example, the zinc was detected in an amount of $31.1 \mathrm{wt} . \%$ (spot spectrum 1) or also 1.4 wt.\% (area spectrum 2, bottom of Figure 8). The total average content of selected elements from the mapping of canvas surface is shown in Table 1.

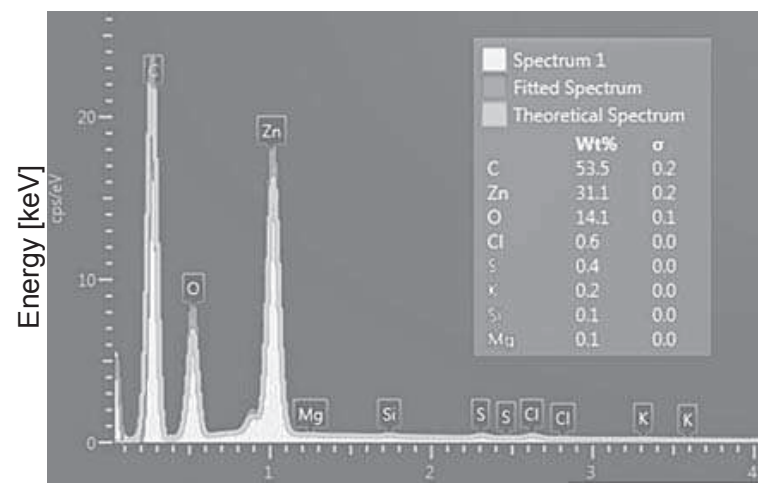

Rate at which ionising elements are detected by a radiological measurement instrument [cps/eV]

Figure 7: EDS spectra of the canvas surface - spot spectrum 1 
While zinc oxide was used in an amount of $2.8 \mathrm{wt} . \%$ of wet coating ratio, in the dry surface layer, zinc only represents approximately $0.7 \mathrm{wt} . \%$.

The dolomite, which originally represented an amount of $2.1 \%$ from wet coating paste, was detected in the dry surface as calcium and magnesium in a total weight of $0.2 \mathrm{wt} \%$. Due to the weight ratio in the dolomite, where $\mathrm{Ca}$ and $\mathrm{Mg}$ represent about one third of (anhydrous) carbonate, a real weight of dolomite in the coating may be assumed to be about $0.6 \mathrm{wt}$.\%.

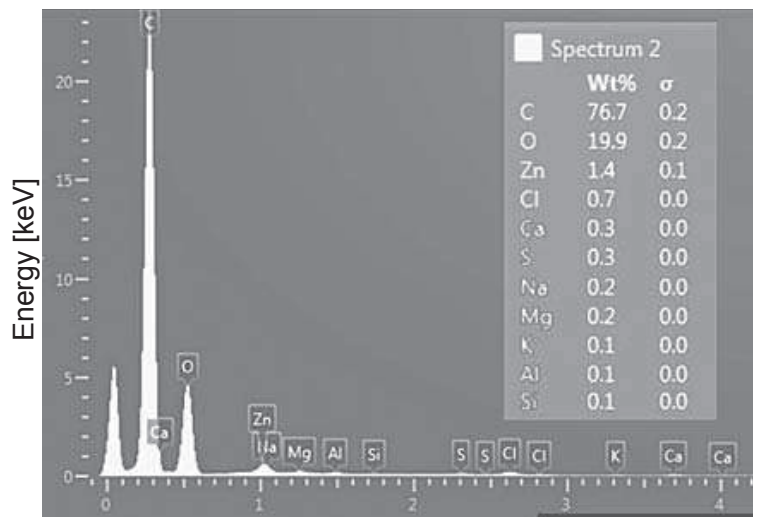

Rate at which ionising elements are detected by a radiological measurement instrument $[\mathrm{cps} / \mathrm{eV}]$

Figure 8: EDS spectra of the canvas surface - area spectrum 2
Table 1: Map sum EDS spectrum of the canvas surface

\begin{tabular}{|c|c|}
\hline Element & Amount [wt.\%] \\
\hline $\mathrm{C}$ & 78.3 \\
\hline $\mathrm{O}$ & 19.4 \\
\hline $\mathrm{Zn}$ & 0.7 \\
\hline $\mathrm{Cl}$ & 0.7 \\
\hline $\mathrm{S}$ & 0.3 \\
\hline $\mathrm{Na}, \mathrm{K}$ & 0.1 \\
\hline $\mathrm{Ca}$ & 0.1 \\
\hline $\mathrm{Mg}$ & 0.1 \\
\hline
\end{tabular}

The results of the buffering and antimicrobial tests of the coated canvas and its two aging versions are shown by the graphs of Figure 9 and Figure 10.

The buffering test in Figure 9 shows how the $\mathrm{pH}$ of the aqueous solutions with coated samples slowly returns to neutral over 15 hours. Figure 10 shows how the number of cultivated CFUs decreased. The test was run for 4 days, and bacterial suspensions with an initial concentration of $3 \times 10^{5} \mathrm{CFU} / \mathrm{mL}$ showed a differently rapid decrease in bacterial growth. It is evident that aqueous solutions with coated canvas showed the best buffering capacity and also the fastest decrease in bacterial growth.

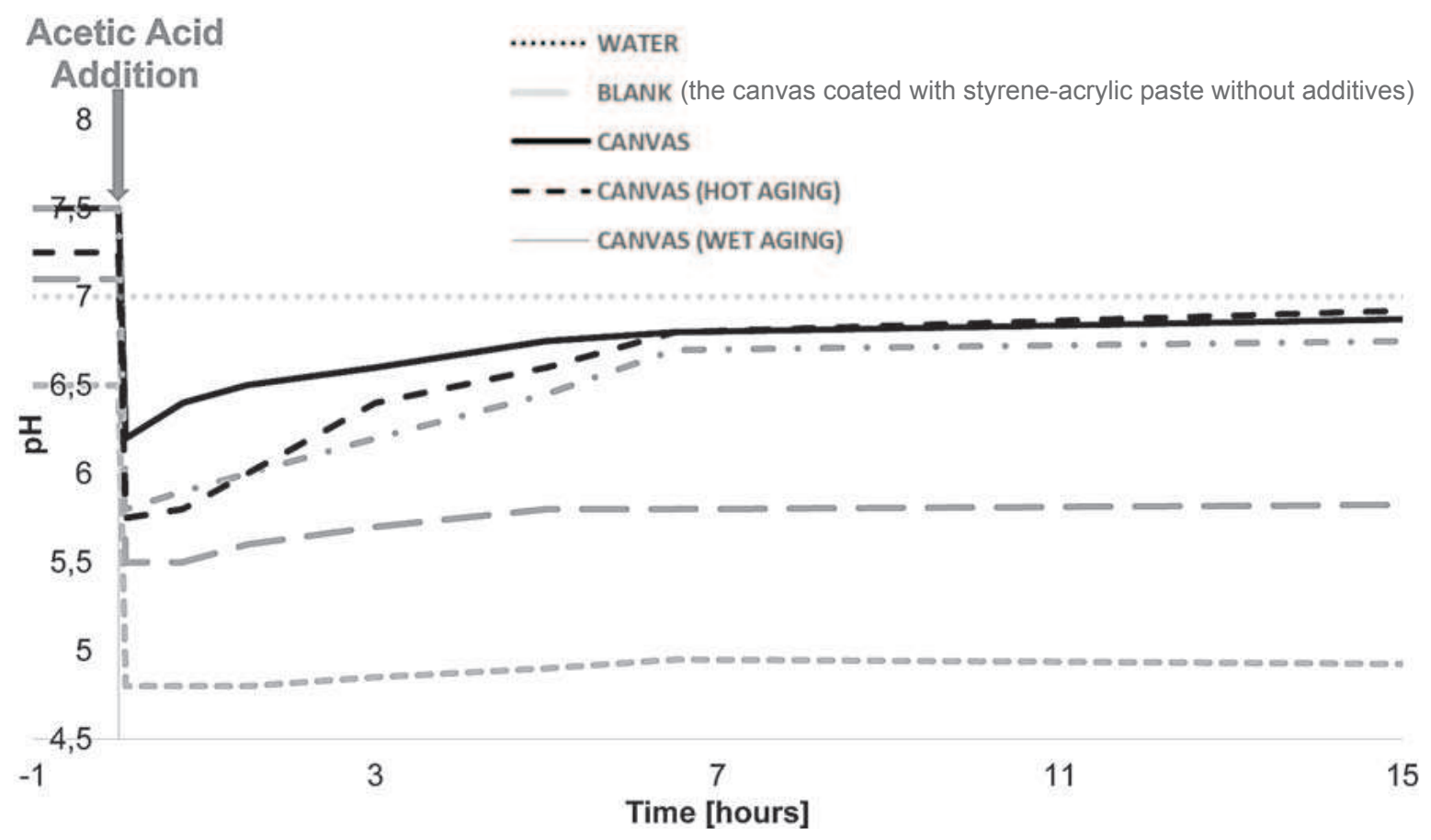

Figure 9: $p H$ changes in water with canvas samples after addition of acetic acid 


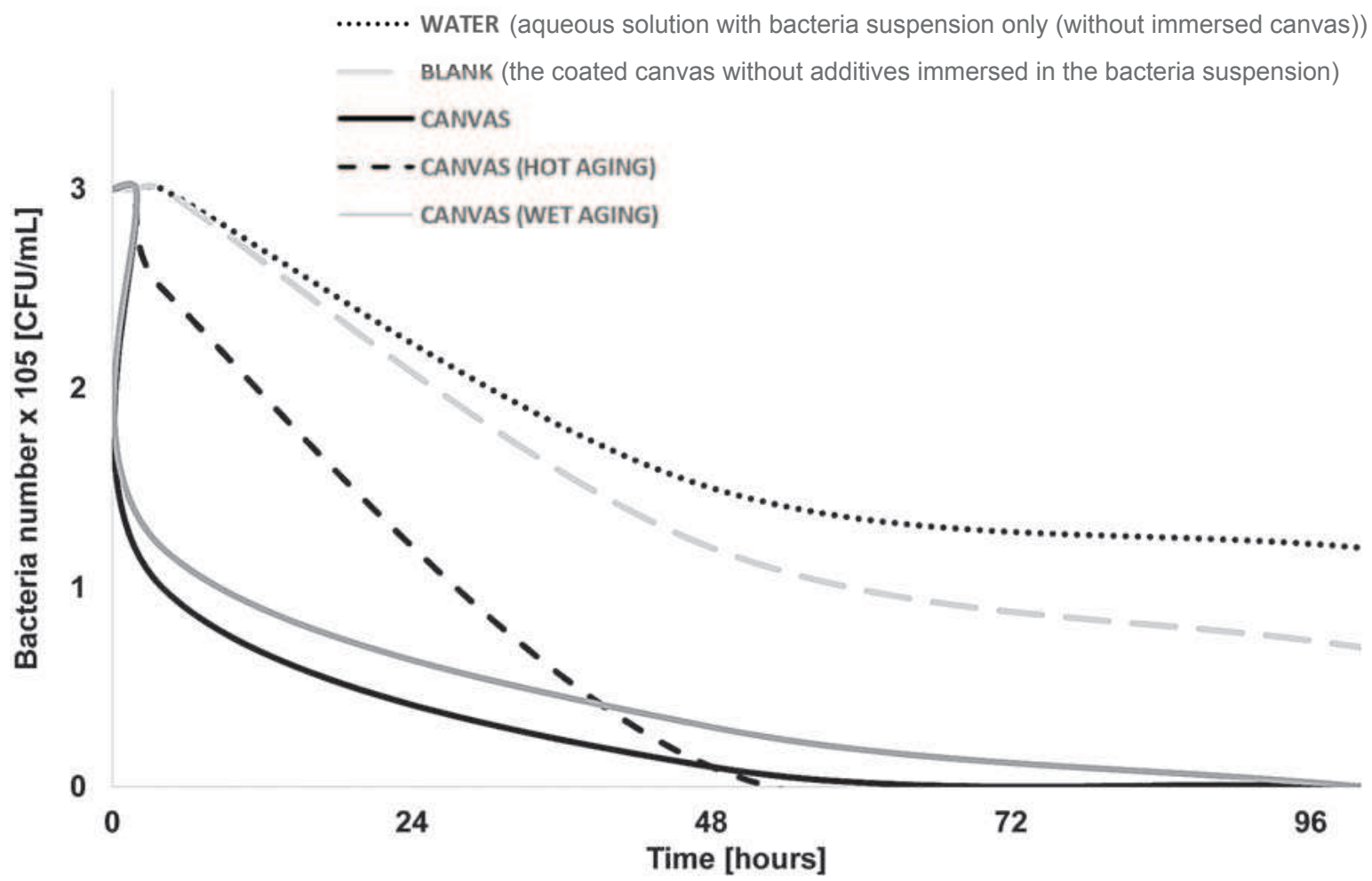

Figure 10: Decrease of the bacteria number in the samples over time

Simultaneously, it can be stated that even after the simulated wet and hot aging, the canvas did not lose any of these abilities.

\section{Discussion}

The buffering and antibacterial ability of coated canvases with both additives was best reflected in samples after 2 days in water. After aging that simulated about 75 years, these canvases have reduced a little all observed properties compared to the original canvas. However, the samples did not lose their antibacterial and buffering properties. At the same time, the canvas after hot aging $\left(6\right.$ days at $\left.105^{\circ} \mathrm{C}\right)$ showed a slightly slower start, especially of antibacterial properties. This leads us to believe that even the visible and prominent particles in the coating surface are partially covered by an acrylate layer, and are essentially passivated until they are in contact with water or wet environment for a long time. On the contrary, this may be an advantage, as particles will become most active up for longer times during long-term storage.

\section{Conclusion}

The aim of this research was to determine the buffering and self-sterilizing properties of canvas with $\mathrm{ZnO}$ and dolomite particles in styrene/acrylic coating. These properties were demonstrated by stress tests with samples in water. The first was done with $27 \mathrm{mM}$ acetic acid and the other using G- and G+ bacteria mixture of $3 \cdot 10^{5} \mathrm{CFU} / \mathrm{mL}$ (Escherichia coli, Staphylococcus epidemidis and Streptococcus mutans). The canvases previously immersed for 48 hours in water buffered the acid slowly for the next 24 hours. Also, the maximum bactericidal effect was achieved after 48 hours of dynamic contact of the surface of the cloths with the bacteria in the aqueous suspension. Artificial accelerated aging slightly decreased these abilities, but canvases did not lose those properties. Hot aging, probably due to the temperature hardening of the acrylic coating, led to a slower start of the antibacterial effect of the cloth. Despite the use of somewhat coarser particles as coating additives, we believe that the tested combination of additives is promising to produce canvas 
designed for long-term storage in wet environments such as book archives.

Acknowledgement

This work was supported by the project No. DF13P01OVV004 Exploration, conservation and care of modern library collections - materials and technologies provided by the Ministry of Culture within the Program of applied research and development of national and cultural identity (NAKI).

\section{References}

1. SZYBILSKI, Miłosz, NOCUŃ-WCZELIK, Wiesława. The effect of dolomite additive on cement hydration. Procedia Engineering, 2015, 108, 193-198, doi: 10.1016/j.proeng.2015.06.136.

2. DOUWES DEKKER, Durban K. The agents used in sugar manufacture. In: Principles of sugar technology. Edited by Pieter Honig. Amsterdam : Elsevier, 1953, pp. 361-430, doi: 10.1016/ b978-1-4832-3252-2.50015-5.

3. IACOBESCU, Remus I., ANGELOPOULOS, George N., JONES, Peter T., BLANPAIN, Bart, PONTIKES, Yiannis. Ladle metallurgy stainless steel slag as a raw material in ordinary portland cement production: a possibility for industrial symbiosis. Journal of Cleaner Production, 2016, 112, 872-881, doi: 10.1016/j. jclepro.2015.06.006.

4. ALBADARIN, Ahmad B., MANGWANDI, Chirangano, ALA'A, Al-Muhtaseb H., WALKER, Gavin M., ALLEN, Stephen J., AHMAD, Mohammad N. M. Kinetic and thermodynamics of chromium ions adsorption onto low-cost dolomite adsorbent. Chemical Engineering Journal, 2012, 179, 193-202, doi: 10.1016/j.cej. 2011. 10.080.

5. KASTYUCHIK, Alexey, KARAM, Antoine, AÏDER, Mohammed. Effectiveness of alkaline amendments in acid mine drainage remediation. Environmental Technology \& Innovation, 2016, 6, 49-59, doi: 10.1016/j.eti.2016.06.001.

6. CHEN, G. C., HE, Zhenli, STOFFELLA, Peter J., YANG, Xiao E., YU, Shen, CALVERT, D. Use of dolomite phosphate rock (DPR) fertilizers to
Comparison with Properties after the Accelerated Aging

reduce phosphorus leaching from sandy soil. Environmental Pollution, 2006, 139(1), 176-182, doi: 10.1016/j.envpol.2004.12.016.

7. SZCZERBA, Jacek, PĘDZICH, Zbigniew. The effect of natural dolomite admixtures on calcium zirconate-periclase materials microstructure evolution. Ceramics International, 2010, 36(2), 535-547, doi: 10.1016/j.ceramint.2009.09.025.

8. MELDRUM, Norman U., ROUGHTON, Francis J. W. Carbonic anhydrase. Its preparation and properties. The Journal of physiology 1933, 80(2), 113, doi: 10.1113/jphysiol.1933.sp003077.

9. JONES, Nicole, RAY, Binata, RANJIT, Koodali, MANNA, Adhar C. Antibacterial activity of $\mathrm{ZnO}$ nanoparticle suspensions on a broad spectrum of microorganisms. FEMS Microbiology Letters 2008, 279(1), 71-76, doi: 10.1111/j.15746968.2007.01012.x.

10. SHARMA, Rajiv K., AGARWAL, Milee, BALANI, Kantesh. Effect of ZnO morphology on affecting bactericidal property of ultra high molecular weight polyethylene biocomposite. Materials Science and Engineering: C, 2016, 62, 843-851, doi: 10.1016/j.msec.2016.02.032.

11. KŘÍŽOVÁ, Hana, WIENER, Jakub. Increase of cotton canvas strength by addition of nanocellulose to the coating. In: Proceedings of 8 th International Conference on Nanomaterials - NANOCON. Ostrava : Tanger, 2016, pp. 324-329.

12. HENRIKSSON, Marielle, BERGLUND, Lars A., ISAKSSON, Per, LINDSTRÖM, Tom, NISHINO, Takashi. Cellulose nanopaper structures of high toughness. Biomacromolecules, 2008, 9(6), 1579-1585, doi: 10.1021/bm800038n.

13. ISO 5630/1: 1982. Paper and board - Accelerated ageing - Part 1: Dry heat treatment.

14. ISO 5630/3: 1982. Paper and board - Accelerated ageing - Part 3: Moist heat treatment at $80{ }^{\circ} \mathrm{C}$ and $65 \%$ relative humidity.

15. ZOU, Xuejun, UESAKA, Tetsu, GURNAGUL, Norayr. Prediction of paper permanence by accelerated aging I. Kinetic analysis of the aging process. Cellulose, 3(3), 243-267, doi: 10.1007/ BF02228805.

16. JIS B 0601: 2001. Surface roughness. Japanese Industrial Standard. 